
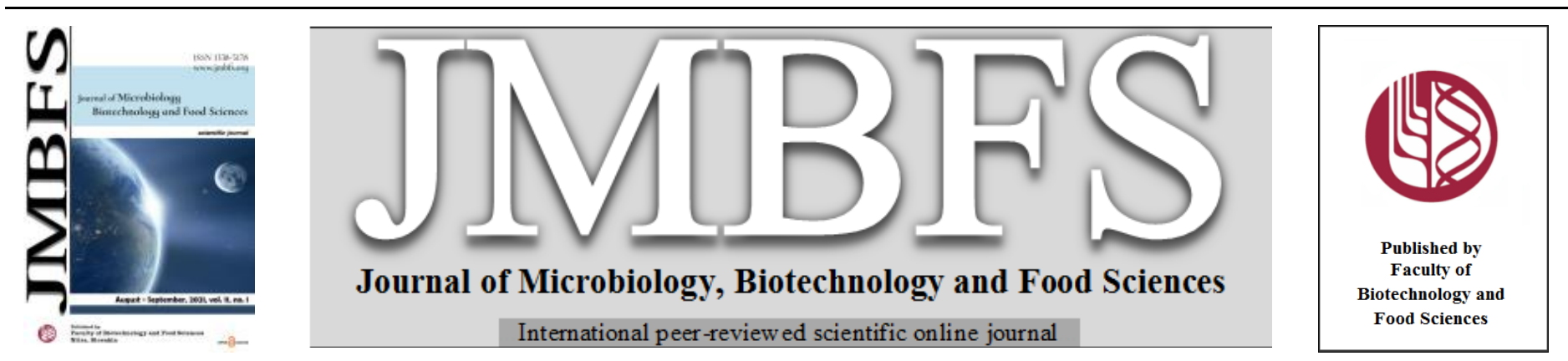

\title{
MEAD OF NATURAL FERMENTATION
}

\section{Bianca Martins Benetole ${ }^{1}$, Winston Pinheiro Claro Gomes ${ }^{1}$, Eduarda Paiva Generoso ${ }^{1}$, Stéfane Verde de Campos ${ }^{1}$, Larissa Nalesso Costa Harder ${ }^{2}$, Valter Arthur ${ }^{3}$, Marcia Nalesso Costa Harder ${ }^{1} *$}

Address(es): Dr. Marcia Nalesso Costa Harder

${ }^{1}$ State Center of Technological Education "Paula Souza“/CEETEPS, Tecnollogy Collegy of Piracicaba "Dep. Roque Trevisan“, Department of Food Technology, Av. Diácono Jair de Oliveira n.651, 13414-155, Piracicaba, São Paulo, Brazil, +55(19) 3413-1702

${ }^{2}$ University of North of Paraná/UENP, Law Department, Av. Getúlio Vargas n. 850, 86400-000, Jacarezinho, Paraná, Brazil, +55(43)3511-3200

${ }^{3}$ Center of Nuclear Energy in Agriculture, São Paulo University, Department of Radiobiology and Environment, Av. Centenário n. 303, 13416-000, Piracicaba, São Paulo, Brazil, +55(19) 3429-4665.

*Corresponding author: marcia.harder@fatec.sp.gov.br

https://doi.org/10.15414/jmbfs.3628

\section{ARTICLE INFO}

Received 24. 8. 2020

Revised 17.3. 2021

Accepted 18. 3. 2021

Published 1. 8. 2021

Regular article OPEN $\partial_{\text {ACCESS }}$

\begin{abstract}
Mead is an alcoholic fermented obtained from the dilution of honey and water in different amounts, depending on the desired alcohol content. This study aimed to evaluate a natural alcoholic fermentation for mead process. Bee honey was used, also Tahiti lemon, Gala apple and black raisin in order to diversify beekeeping products and to evaluate the effect. The production of pure mead (A) was from $17.60^{\circ}$ Brix, the production of lemon mead (B) was from $16.80^{\circ}$ Brix, the production of mead raisin (C) was from $19.60^{\circ}$ Brix, while mead with apple (D) was from $16.10^{\circ}$ Brix, and all mead were produced from wild yeast present in the environment. The alcoholic fermentation occurred at room temperature for 56 days and obtained alcohol content (v/v) and volatile acidity (mEq/l) in A of $4.92 \%$ and 24.47 , in B of $1.78 \%$. and 8.71, in C of $6.47 \%$ and 11.26 and in D of $1.53 \%$ and 6.46 , respectively. Moreover, after the 56 days of maturation of the mead were obtained the methanol (mg/l) and alcoholic (v/v) content, in this order, in A of 666.67 and $11.04 \%$, in B of $1,000.00$ and $6.71 \%$, in C 200.00 and $13.28 \%$ and in D 833.33 and 5.06\%. From the results obtained can be concluded that only C is within the legislation of the mead standard, but that $\mathrm{A}$ and $\mathrm{C}$ yeasts presented the highest fermentation potential. Thus, further studies on mead production and a reassessment of the quality and identity standard agreed by Normative Instruction no 34/2012 are required.
\end{abstract}

Keywords: wild yeast, beverage, Apis mellifera honey, honey beverage, beverage analysis

\section{INTRODUCTION}

The focus of the present study is natural fermentation. And the choice of mead by this process was due to the growing search for foods categorized as "comfort food", which are foods that recall a pleasurable mental state, especially associated with a nostalgic and sentimental appeal, in addiction refer to foods that are homemade (Wansink, Cheney \& Chan, 2003). Therefore, handcrafted fermented drinks are classic examples of this type of food. And it includes necessarily mead in this type of drink, which has been produced in a rustic and empirical way since ancient times (Peixoto, Carvalho \& Estvinho, 2014) and as a high added value drink due to the slow manufacturing process and the raw material used.

The production of mead in many countries has a great economic importance, where there are several published scientific studies of the properties of the honey that makes this drink (Roldán et al., 2011; Souza, Dias \& Teixeira., 2018). A simple analysis of the product demonstrates the nutritional richness of its composition, including vitamins and minerals (Azeredo, Azeredo \& Dutra, 2003; Silva et al., 2016), in addition to the honey containing micronutrients that make up various properties with the most important benefits, noteworthy antimicrobial, anti-inflammatory, antibiotic, energetic, anti-caries and healing actions (Abadio Finco, Moura \& Galvão, 2016; Silva et al., 2016).

By the way, because of this the honey is consumed on a large scale worldwide, gaining great importance in the human diet for its therapeutic, nutritional and functional qualities (Picoli, 2000; Silva et al., 2003; Fernandes, Locatelli \& Scartazzini, 2009). Consequently, it is widely used in the pharmaceutical, cosmetics and food industries (Pereira, 2008; Fernandes, Locatelli \& Scartazzini, 2009).

Mead is considered by many people the oldest fermented alcoholic in the world. Studies even show residues of this drink in ceramics in China, dating more than 7,000 years BC, having subsequently expanded to Ancient Egypt, Greece, the Roman Empire, and Medieval Europe (Kristbergsson \& Oliveira, 2016; Souza, Dias \& Teixeira, 2018).
In addition, the medieval Nordic literature, according to Campos (2015), presents the mead mythology, which the ingredient used to make the drink, honey, was difficult to access at that time because the swarms often died, run away or disappeared, or for being located in high-risk regions to those who collected them (Embrapa, 2003; Bacaxixi et al., 2011). Because of this, the drink was considered a bond of union between men and gods, that means the mead had a sacred character, because it was a drink within reach of few. So the consumption was generally by the wealthier, like kings and warriors and in sacred rituals. The height of the bond between the gods was attained through the state of drunkenness: the greater the drunkenness caused by the fermented honey, the greater the link between the individual and the gods and in commemorations of diverse victories at that time, as wars and abundant harvests, in which rituals were necessary offering the drink in great proportions to the gods accompanied with banquet (Campos, 2015).

Another historical fact cited by Berry (2007) and Lauermann et al.(2015) is that mead is also known as honey wine and has its origin reported in Africa for thousands of years, where the modern production through utensils and techniques was recorded 2,000 years BC. Although mead is an alcoholic beverage fermented through honey, water and yeast, herbs, spices and fruits can be added to it, which give it a wide variety, as can be seen from the types of mead in the Table 1.

In fermentations of alcoholic beverages such as the most common yeasts used as Sacharomyces cereviseae, which has the function of converting sugar into ethyl alcohol and producing other important substances in the characterization of the drink, such as aromatic compounds. As yeasts are eukaryotes, single-celled belonging to the kingdom of fungi, heterotrophic and multiplied by budding, rapid abrasion in its population, especially in the environment in which it is present or sugar. As honey is rich in sugars such as fructose, glucose, maltose and sucrose, clearly a yeast proven by the fermentation of honey is a Sacharomyces cereviseae (Falasca, Muchagata \& Bassan, 2010; Ribeiro Junior, Canaver \& Bassan, 2015). 
Table 1 Mead shunts

\begin{tabular}{ll}
\hline Denomination & Ingredients \\
\hline Mead & Water and honey fermented drink \\
\hline Great mead & Aged mead \\
\hline Melomel & Fruit-added mead (except grapes) \\
\hline Pyment & Grape mead (preferably wine grapes) \\
\hline Cyser & Apple mead \\
\hline Metheglin & Mead with spice, hops and even rose petals \\
\hline Braggot & Mead with added malt \\
\hline Hippooras & Pepper mead \\
\hline Brandy & $\begin{array}{l}\text { Mead that after a fermentation step there is an addition } \\
\text { of honey and honey brand obtained by distilling the } \\
\text { mead }\end{array}$ \\
\hline
\end{tabular}

Source: Adapted from Berry (2007); Iglesias et al. (2014); Brunelli (2015); Freitas et al. (2017).

Mead is obtained through the preparation of the wort, preparation of vat feet (also called inoculum, which consists of a suspension of microorganisms of adequate concentration used for the fermentation of the must), inoculation of yeasts, fermentation, clarification and filling. The fermentation of the drink can take a few months and even years, depending on honey, yeast, nutrition and $\mathrm{pH}$ control (Mattietto, 2006; Milesk, 2016). According to Katz (2012), fermented beverages after storage continue to develop through several slow chemical reactions even after fermentation has stopped, it gets its name from aging, as they are matured over time in bottles.

In the maturation of this fermented drink, the maturation and storage times are not universal. Generally, the maturation of alcoholic beverages can occur in glass containers that provide the organoleptic and physico-chemical characteristics of the traditionally manufactured product, which consists of a bittersweet flavor and a spicy aroma (EU, 2012; Mileski, 2016). However, in other containers, such as wooden, it is not recommended, because during the fermentation, the growth of microorganisms such as molds can occur in the pores of the wood, contaminating and altering the organoleptic values of the drink (Katz, 2012).

During the production of the honey drink, several precautions must be used to avoid delay, the mixture does not result in the honey wine due to the stress of the yeast, such as nutrition, temperature, $\mathrm{pH}$, and so that they do not meet the need for the microorganism of interest and favor other microorganisms, such as bacteria. Because changing the conditions of the environment will consequently change the desired characteristics in the drink.

As already seen, the fermentation for the manufacture of mead was natural, using only wild yeasts and in which fermentation is characterized by the microorganisms present spontaneously in food and environments. And so that fermentation is spontaneous, starting with existing microorganisms. And, therefore, the type of fermentation always depends on what was used. For example, if fermentation starts with a grape, yeasts start an alcoholic fermentation; however, if fermented from milk or vegetables, the lactic acid bacteria will dominate and start a lactic fermentation (Katz, 2012).

Although natural fermentation has been widely used in the past, wild yeasts can harm alcoholic fermentation processes and, in contrast, some can also bring positive points proven through analysis. In the isolation and evaluation of some wild yeasts regarding their fermentative potential in ethanol production, it was found that the hegemony and rusticity of these strains are associated with an excellent fermentative performance (Ferrari et al., 1980; Parazzi \& Oliveira, 1996; Adrietta et al., 2007; Moreira et al., 2013). Likewise, wild yeasts are more resistant to adverse conditions, especially regarding $\mathrm{pH}$ and temperature (Cecato-Antonini \& Parazzi, 1996; Moreira et al., 2013)

\section{MATERIAL AND METHODS}

The experiment was carried out at the Food, Chemistry, Microbiology and Chromatography Laboratories, at the Technology College of Piracicaba "Dep. Roque Trevisan", in the city of Piracicaba, São Paulo State, Brazil, and the activities will be detailed.

\section{Reagents and materials}

Africanized bee honey, water, apple, lemon and raisin were purchased at the local market in the city of Piracicaba and immediately forwarded to the laboratories in order to be processed. The production of pure mead of honey (type A) was from $17.60^{\circ}$ Brix, the production of lemon mead (type B) was from $16.80^{\circ}$ Brix, the production of mead raisin (type C) was from $19.60^{\circ}$ Brix, while mead with apple (type D) was from $16.10^{\circ}$ Brix, and all mead were produced from wild yeast present in the environment.

The absolute ethyl alcohol $\left(\mathrm{C}_{2} \mathrm{H}_{5} \mathrm{OH}\right)$ used for the analysis in chromatography is of analytical standard grade (Neon Brand), while the methyl alcohol $\left(\mathrm{CH}_{3} \mathrm{OH}\right)$ used for the analysis in chromatography is of standard chromatographic grade (Brand LiChrosolv ${ }^{\circledR}$ Merck), while the $0.01 \mathrm{M}$ sodium hydroxide solution and the methylene blue-sodium citrate solution were those that were available in the laboratory.

\section{Fermentation}

To carry out the natural fermentation process, honey, apple, lemon and raisin were left in contact with the atmosphere, so that there was contact with the microorganisms.

After exposure, a 4 to 1 ratio of water and honey was added in a 21 bottle, and 4 types of mead recipes were prepared to compare the alcohol content, with variations in accordance with the Table 02 .

Table 2 Mead methods

\begin{tabular}{lllll}
\hline Ingredients & type A & type B & type C & type D \\
\hline Honey & 200.00 & 200.00 & 200.00 & 200.00 \\
\hline Water & 800.00 & 800.00 & 800.00 & 800.00 \\
\hline Lemon & - & 92.00 & - & - \\
\hline Raisin & - & - & 100.00 & - \\
\hline Gala apple & - & - & - & 146.00 \\
\hline So
\end{tabular}

Source: Authors. * Values shown in grams

\section{Instrumental}

The alcohol content determinations were performed in a gas chromatograph PerkinElmer model Clarus 600, with flame ionization detector (flame ionization detector - FID). A capillary column PerkinElmer model Elite-WAX with dimensions of $30 \mathrm{~m} \times 0.25 \mathrm{~mm} \times 0.5 \mu \mathrm{m}$ was used. The carrier gas used was nitrogen at a flow rate of $1.20 \mathrm{ml} . \mathrm{min}^{-1}$, of hydrogen was $45 \mathrm{ml} . \mathrm{min}^{-1}$ and the synthetic air was $450 \mathrm{ml} \cdot \mathrm{min}^{-1}$, all with a high degree of purity $(99.999 \%)$. The sample injection volume was $300 \mu \mathrm{L}$ at a speed of $250 \mu 1 . \mathrm{s}^{-1}$, using the "split" of 1:10. The oven temperature was $212^{\circ} \mathrm{F}$ per 5 minutes. The injector temperature was $302^{\circ} \mathrm{F}$ and the detector $572^{\circ} \mathrm{F}$.

The gas chromatograph also has an automatic sampler of the Combipal brand, model CTC Analytics, Pal System, with the oven to Headspace.

\section{Preparation of standard solutions}

Standard solutions containing absolute ethyl alcohol, expressed in v/v (volume in $\mathrm{mL}$ of the analyte and $100 \mathrm{~mL}$ of solution), were prepared with the following concentrations: standard $1\left(0.5 \%\right.$ of $\left.\mathrm{C}_{2} \mathrm{H}_{5} \mathrm{OH}\right)$, standard $2\left(1.0 \%\right.$ of $\left.\mathrm{C}_{2} \mathrm{H}_{5} \mathrm{OH}\right)$, standard $3\left(2.0 \%\right.$ of $\left.\mathrm{C}_{2} \mathrm{H}_{5} \mathrm{OH}\right)$, standard $4\left(3.0 \%\right.$ of $\left.\mathrm{C}_{2} \mathrm{H}_{5} \mathrm{OH}\right)$, standard $5(4.0 \%$ of $\left.\mathrm{C}_{2} \mathrm{H}_{5} \mathrm{OH}\right)$, standard $6\left(5.0 \%\right.$ of $\left.\mathrm{C}_{2} \mathrm{H}_{5} \mathrm{OH}\right)$, standard $7\left(6.0 \%\right.$ of $\left.\mathrm{C}_{2} \mathrm{H}_{5} \mathrm{OH}\right)$ standard $8\left(7.0 \%\right.$ of $\left.\mathrm{C}_{2} \mathrm{H}_{5} \mathrm{OH}\right)$, standard $9\left(8.0 \%\right.$ of $\left.\mathrm{C}_{2} \mathrm{H}_{5} \mathrm{OH}\right)$, standard $10(9.0 \%$ of $\left.\mathrm{C}_{2} \mathrm{H}_{5} \mathrm{OH}\right)$, standard $11\left(10.0 \%\right.$ of $\left.\mathrm{C}_{2} \mathrm{H}_{5} \mathrm{OH}\right)$, standard $12\left(11.0 \%\right.$ of $\left.\mathrm{C}_{2} \mathrm{H}_{5} \mathrm{OH}\right)$, standard $13\left(12.0 \%\right.$ of $\left.\mathrm{C}_{2} \mathrm{H}_{5} \mathrm{OH}\right)$ e standard $14\left(14.0 \%\right.$ of $\left.\mathrm{C}_{2} \mathrm{H}_{5} \mathrm{OH}\right)$. The analytical curve was constructed and $\mathrm{R}^{2}$ was obtained 0.993197 , presented by the equation $\mathrm{y}=(155.812613)+(950.097041) x$. Standard solutions containing methyl alcohol, expressed as $\mathrm{w} / \mathrm{v}$ (weight in grams of the analyte and $100 \mathrm{~mL}$ of solution), were prepared with the following concentrations: standard $1(0.0396 \%$ of $\left.\mathrm{CH}_{3} \mathrm{OH}\right)$, standard $2\left(0.0792 \%\right.$ of $\left.\mathrm{CH}_{3} \mathrm{OH}\right)$, standard $3\left(0.1188 \%\right.$ of $\left.\mathrm{CH}_{3} \mathrm{OH}\right)$, standard $4\left(0.1584 \%\right.$ of $\left.\mathrm{CH}_{3} \mathrm{OH}\right)$, standard $5\left(0.1980 \%\right.$ of $\left.\mathrm{CH}_{3} \mathrm{OH}\right)$, standard 6 $\left(0.2376 \%\right.$ of $\left.\mathrm{CH}_{3} \mathrm{OH}\right)$, standard $7\left(0.2772 \%\right.$ of $\left.\mathrm{CH}_{3} \mathrm{OH}\right)$ e standard $8(0.3168 \%$ of $\left.\mathrm{CH}_{3} \mathrm{OH}\right)$. The analytical curve was constructed and the $\mathrm{R}^{2}$ value of 0.999190 was obtained, presented by the equation $\mathrm{y}=(-12.271469)+(7186.637974) \mathrm{x}$.

\section{Analysis of alcohol content and methanol}

In order to perform the analysis of alcohol content, 4 samples were collected every 7 days after the start of mead preparation and then another 7 days and so on until completing 56 days, totaling 36 samples, added after four more samples on the $57^{\text {th }}$ day. To carry out maturation, the racking and filtration process was carried out, which consists of preventing the mead from being in contact with the sludge formed at the bottom of the container and with suspended materials (yeasts) (Mattietto, 2006; Brunelli, 2015). At the end of the maturation process, which took another 56 days after the penultimate collection and, therefore, after the $112^{\text {th }}$ day of the beginning of the fermentation process, when the content of methanol and ethanol in these samples was then carried out, and thus decanting of yeasts that could still be in suspension after filtration. And all samples were then incubated in the oven of the automatic sampler to use the Headspace extraction, at $140^{\circ} \mathrm{F}$ during $5 \mathrm{~min}$ with a stirring of $500 \mathrm{rpm}$. After they were injected into the chromatograph, one by one.

\section{Physicochemical analysis}

Analyzes were carried out in triplicate of $\mathrm{pH}$ and soluble solids ( $\left.{ }^{\circ} \mathrm{Brix}\right)$. And for that we used the Quimis Q-400MTS bench pHmeter model and the Homis VBR$32 \mathrm{~T}$ portable refractometer model with scale from 0 to $32 \%$ of soluble solids Samples were taken after preparing the recipes, repeating this process every 7 days, for a period of 56 days, as well as on the $57^{\text {th }}$ day. 


\section{Volatile acidity}

For this analysis, it was used the Tecnal Volatile Acidity Determinator TE-0871, methodology recommended by the Adolfo Lutz Institute (2008) to determine the titratable volatile acidity of wines and other fermented beverages by volumetry, after steam distillation, following the formula:

$\mathrm{VA}=(\mathrm{n} \times \mathrm{f} \times \mathrm{N} \times 1000) / \mathrm{V}$

In which:

$\mathrm{VA}=$ Volatile acidity, in $\mathrm{mEq} / \mathrm{L}$

$\mathrm{n}=$ Volume of sodium hydroxide solution spent on titration, in $\mathrm{mL}$

$\mathrm{f}=$ Sodium hydroxide solution correction factor

$\mathrm{N}=$ Normality of sodium hydroxide solution

$\mathrm{V}=$ Sample volume, in $\mathrm{mL}$

\section{Cell viability}

The sodium methylene blue citrate solution was prepared as reported by Ceccato-Antonini (2010), weighing $0.01 \mathrm{~g}$ of methylene blue, dissolving it in a small amount of sterile distilled water, adding $2 \mathrm{~g}$ of sodium citrate homogenizing the substance and completing the volume to $1000 \mathrm{~mL}$ with sterile distilled water. The slides (Neubauer chamber) were observed in an Olympus BX41 light-field optical microscope coupled to an Olympus DP72 camera, being digitally documented in the DP2-BSW software.

\section{RESULTS AND DISCUSSION}

\section{Fermentation}

The analysis of the evolution of the fermentation process was done by monitoring the $\mathrm{pH}$, soluble solids and alcohol content over the months, as shown in Figures $1,2,3$ and 4.

For Figure 1 there are showed the $\mathrm{pH}$, tenor of soluble solids and tenor of alcohol results for sample Type A (pure mead of honey).

Type A - pH vs. Brix vs. alcohol content

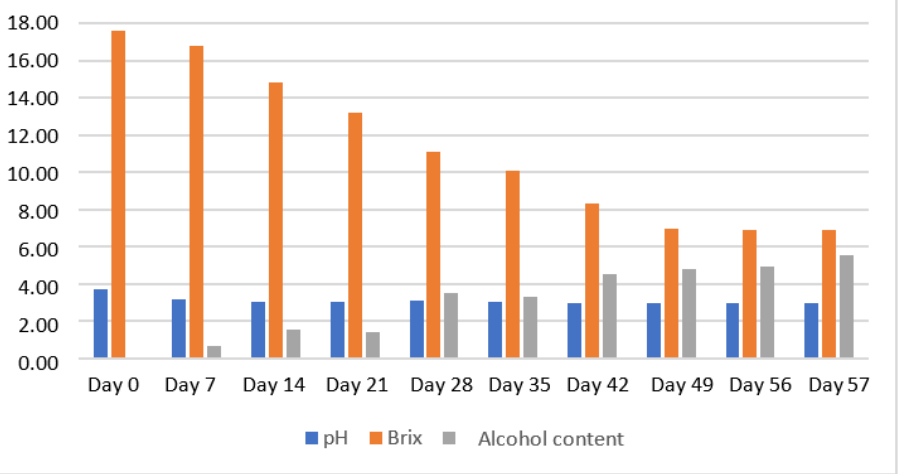

Figure 1 Evolution of $\mathrm{pH}$, soluble solids $\left({ }^{\circ} \mathrm{Brix}\right)$ and alcohol content of type $\mathrm{A}$ mead during fermentation

At Figure 2 is possible to see the $\mathrm{pH}$, tenor of soluble solids and tenor of alcohol results for sample Type B (lemon mead).

Type B - pH vs. Brix vs. alcohol content

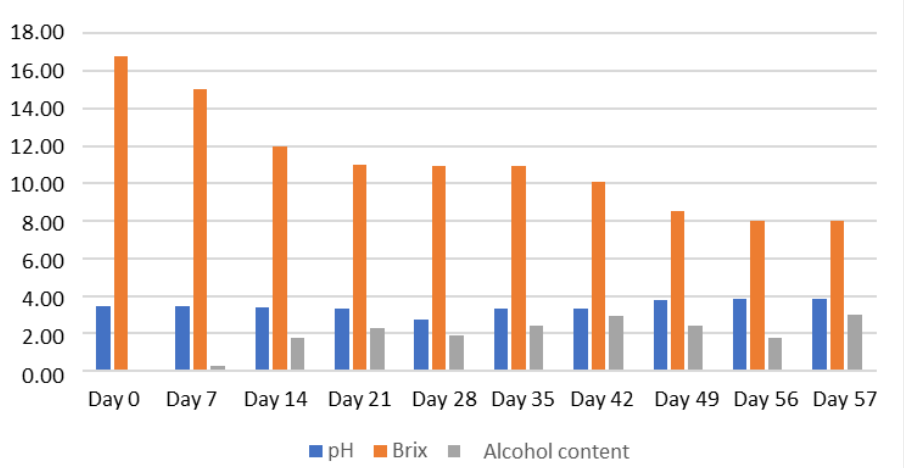

Figure 2 Evolution of $\mathrm{pH}$, soluble solids $\left({ }^{\circ} \mathrm{Brix}\right)$ and alcohol content of type $\mathrm{B}$ mead during fermentation
In Figure 3 we can observe the $\mathrm{pH}$, tenor of soluble solids and tenor of alcohol results for sample Type $\mathrm{C}$ (mead raisin).

Type C - pH vs. Brix vs. alcohol content

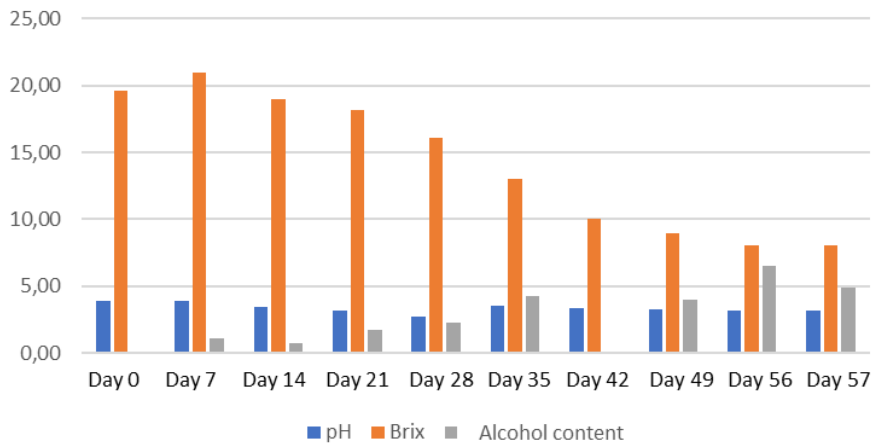

Figure 3 Evolution of $\mathrm{pH}$, soluble solids ( ${ }^{\mathrm{o}}$ Brix) and alcohol content of mead type $\mathrm{C}$ during fermentation

* Day 42 alcohol content, the sample ended up being lost.

For Figure 4 there are showed the $\mathrm{pH}$, tenor of soluble solids and tenor of alcohol results for sample Type D (mead with apple).

Type D - pH vs. Brix vs. alcohol content

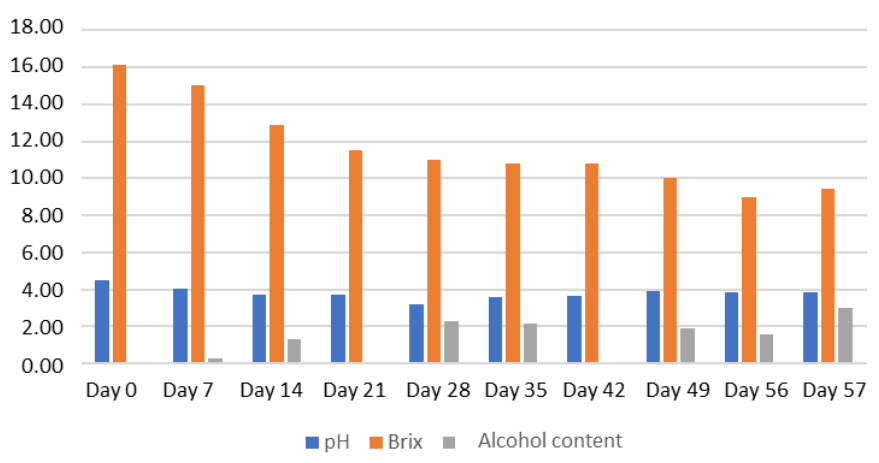

Figure 4 Evolution of $\mathrm{pH}$, soluble solids ( ${ }^{\circ}$ Brix) and alcohol content of type D mead during fermentation

* Day 42 alcohol content, the sample ended up being lost.

Through $\mathrm{pH}$ and soluble solids analyzes performed weekly, as well as visua analyzes of the four different types of meads, it was observed that meadows type $\mathrm{B}$ and D had their soluble solids content stabilizing as from the twenty-first day, thus indicating that yeasts were probably reaching their maximum capacity to tolerate the level of alcohol contained in each mead or until they were dying due to the below ideal $\mathrm{pH}$, especially in the case of type $\mathrm{B}$, in which the minimum $\mathrm{pH}$ was never reached, as indicated by Silva (2016). The $\mathrm{pH}$ of musts traditionally used in the manufacture of alcoholic beverages varies between 3.5 and 4.5. And according to Aquarone, Lima \& Borzani (2001) and Oliveira et al. (2001), pH values between 3 and 4 do hinder bacterial contamination.

Although the $\mathrm{pH}$ of type A mead is also below that indicated for fermentation, soluble solids and visual analyzes indicated that the fermentation process continued to occur. Therefore, sodium hydroxide $(\mathrm{NaOH})$ was then added on the forty-sixth day only to mead types $\mathrm{B}$ and $\mathrm{D}$, with the aim of increasing their $\mathrm{pH}$ and, consequently, their cell viability so that the fermentation process would continue to occur.

In $650 \mathrm{~mL}$ of mead type $\mathrm{B}$ with an initial $\mathrm{pH}$ of $3.38,79.5 \mathrm{~mL}$ of $\mathrm{NaOH}$ reaching a final $\mathrm{pH}$ of 4.0 , while in the type $\mathrm{D}$ mead it started from $850 \mathrm{~mL}$ and a $\mathrm{pH}$ of 3.41 adding $45.9 \mathrm{~mL}$ of $\mathrm{NaOH}$ and reaching a final $\mathrm{pH}$ of 4.00 , a value within the recommended for the alcoholic fermentation process.

\section{Analysis of alcohol content and volatile acidity}

The alcoholic content and volatile acidity in the mead (Table 3 ) are presented by Normative Instruction No 34/2012, with the maximum allowed amount of acetic acid of $20 \mathrm{mEq} / \mathrm{L}$ (milliequivalent-gram per liter) and ethyl alcohol is $4 \%$ up to $14 \%$, in $\mathrm{v} / \mathrm{v}$ at $68^{\circ} \mathrm{F}$. 
Table 3 Alcohol content on the 56th day

\begin{tabular}{ccc}
\hline Recipe & $\begin{array}{c}\text { \% of alcohol content } \\
(\mathrm{v} / \mathrm{v})^{*}\end{array}$ & Volatile Acidity $(\mathrm{mEq} / \mathrm{L})^{*}$ \\
\hline Type A & 4.92 & 24.47 \\
\hline Type B & 1.78 & 8.71 \\
\hline Type C & 6.47 & 11.26 \\
\hline Type D & 1.53 & 6.46 \\
\hline *Medium values & &
\end{tabular}

Only mead C reached the standards of quality and identity that legally characterizes them as such, as it had a content of ethyl alcohol and volatile acidity within the stipulated by Brazil (2012) for a fermented honey drink to be considered mead. However, types B and D meads had ethyl alcohol content below that determined by Brazil (2018), which strictly characterizes them only as a fermented honey drink, even with volatile acidity below the maximum limit. Mead A, on the other hand, cannot be characterized as mead according to the criteria of Brazil (2012), because despite having an alcohol content above the minimum limit, it also had volatile acidity above the maximum limit.

And, according to Gomes (2010) and according to Oliveira Neto (2013) yeasts, microorganisms responsible for the fermentation process, produce ethyl alcohol from the amount of total soluble solids ( ${ }^{\circ}$ Brix), which can explain the different alcoholic levels obtained in analyzes of the different meads, since the mead type C, which had the highest initial Brix, which was $19.60^{\circ}$ Brix, also had the highest final alcohol content, of $6.47 \%$. And according Mileski (2016) which started from $27^{\circ}$ Brix with the addition of selected yeast (Saccharomyces cerevisiae), the alcohol content obtained was $15.69 \%$, on average, presenting the possibility that wild yeasts may also have been responsible due to the low alcohol content of meads.

Each mead was produced in a different location. And in types B, C and D different substrates were added, thus indicating that the yeasts, despite being all wild and therefore adapted to the environment, as described by Vicente (2015), may be of different strains, which would also explain the difference in the final alcoholic content of meads, mainly types B and D, which had the lowest levels. Furthermore, according to Food Ingredients Brazil (2013), lemon has an antimicrobial effect thanks to citrus oil. Castro \& Lima (2011) with according to Sarto \& Zanusso Junior (2014) reported his expressive antifungal potential, while Kosker, Feller \& Esselen (1949) apud Ouvires (1997) reported yeast inhibition in apple cider.

It should also be borne in mind that the alcohol content of the four types of meads on the fifty-seventh day of the process without pasteurization was higher than on the fifty-sixth day of the process. And this shows that the pasteurization process was carried out correctly, which was proved by the analysis of the cell viability made, since the samples of the meads in which there was no pasteurization, the fermentation process continued. In addition, it is to be considered that part of the ethanol may have evaporated during pasteurization, since it was made by hand. The methanol and alcoholic content after 56 days of maturation, with a total of 112 days since the beginning of the fermentation process, was obtained according to Table 4, where maturation is the aging period that gives specific organoleptic characteristics in the drink due to the material used (Mileski, 2016).

Table 4 Values of methanol and ethanol content after maturation

\begin{tabular}{lccc}
\hline \multirow{2}{*}{ Recipe } & $\begin{array}{c}\text { \% of Alcohol } \\
\text { content }(\mathrm{v} / \mathrm{v})^{*}\end{array}$ & \multicolumn{2}{c}{ \% of Methanol content * } \\
\cline { 3 - 4 } & 11.04 & 0.07 & $\mathrm{mg} / \mathrm{l}$ \\
\hline Type A & 6.71 & 0.10 & 666.67 \\
\hline Type B & 13.28 & 0.02 & $1,000.00$ \\
\hline Type C & 5.06 & 0.08 & 200.00 \\
\hline Type D & & & 833.33 \\
\hline
\end{tabular}

* Average and approximate values

The alcohol content shown in Table 4 characterizes meads legally by this parameter determined by Brazil (2012). However, the values presented are very different from what is shown in Table 3. And the authors believe that the increase in alcohol content is due to the maturation process and the decantation of yeasts. And they understand that further studies on the matter are necessary since nothing was found in the literature to explain the cause of the increase in alcohol content.

Normative Instruction No. 14/2018 was used for the methanol content parameter, which establishes the quality and identity standard for wine and grape and wine derivatives, since mead is considered honey wine. Thus, the level of adequacy for this parameter was established, the maximum value of $400 \mathrm{mg} . \mathrm{l}^{-1}$ of methyl alcohol present in the mead.

Thus, based on the information in Table 4, only Type $\mathrm{C}$ mead can be characterized as viable for consumption and commercialization, since the methanol content was $200 \mathrm{mg} . \mathrm{l}^{-1}$, while Types A, B and D, presented high levels above the stipulated, where in Type $\mathrm{B}$ and $\mathrm{D}$ it is expected due to the presence of pectin, which is a precursor to methanol, which comes from lemon and apple in their formulations. Where in lemon, as reported by Mendonca et al. (2006), it is rich in pectin, presenting $54.62 \%$ in dry matter, involving flavedo, albedo and bagasse. And in the apple according to the works of Levigne, Ralet $\&$ Thibault (2002), Yapo et al. (2006) and Fertonani (2006) the content of pectin is between 25 and $30 \%$. In the Type A mead, the high methanol value presented was not expected, since in its formulation no fruit was used to make the presence of pectin available, but as the volatile acidity also presented a high value, what can be proposed is the contamination by microorganisms that carry genes that encode methanol-producing enzymes.

\section{Cell viability}

Based on the evolution of the content of soluble solids during the fermentation process, the cell viability of the four types of mead was made, aiming at a more detailed knowledge about the microorganisms that were present in the yeasts, since the fermentation was done naturally.

The determination of yeast cell viability (Figures 5 and 6 ) was carried out according to Oliveira-Freguglia and Horii (1998), using a solution of methylene blue-sodium citrate as a dye. The samples were analyzed using a microscope and the result expressed as a percentage (\%) of live cells determined using the following formula:

$\mathrm{V}=\mathrm{CV} / \mathrm{CT} \times 100$

In which:

$\mathrm{V}=$ Cell viability

$\mathrm{CV}=$ Number of living cells

$\mathrm{CT}=$ Number of total cells (live + dead)

Based on the cell viability formula and in Figure 5, it was possible to determine the cell viability of the four types of mead on the thirty-sixth day of the process, with cell viability of type A $38.14 \%, 19.10 \%$ of type B, $29.41 \%$ that of type C and $10.20 \%$ that of type D. Based on the cell viability values, together with the $\mathrm{pH}$ and Brix analyzes, it was decided to add sodium hydroxide only in types B and mead. D.

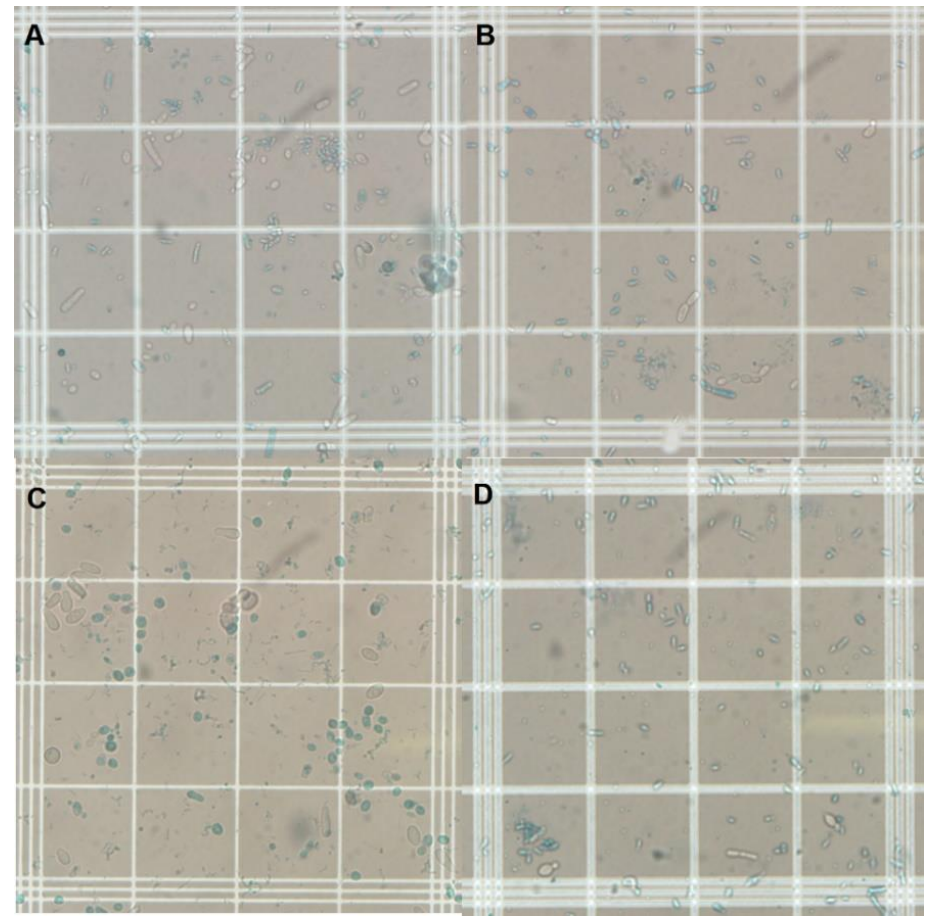

Figure 5 Yeasts of the four types of mead in the Neubauer chamber on the 36th day of the process. A) Mead of type A. B) Mead of type B. C) Mead of type C. D) Mead of type D

Eleven days after the addition of sodium hydroxide, a new determination of cell viability was performed with the four types of mead, but there was no significant increase in the viability of type B and D mead, requiring a new analysis, which was made seven days after the first (Figure 6). 


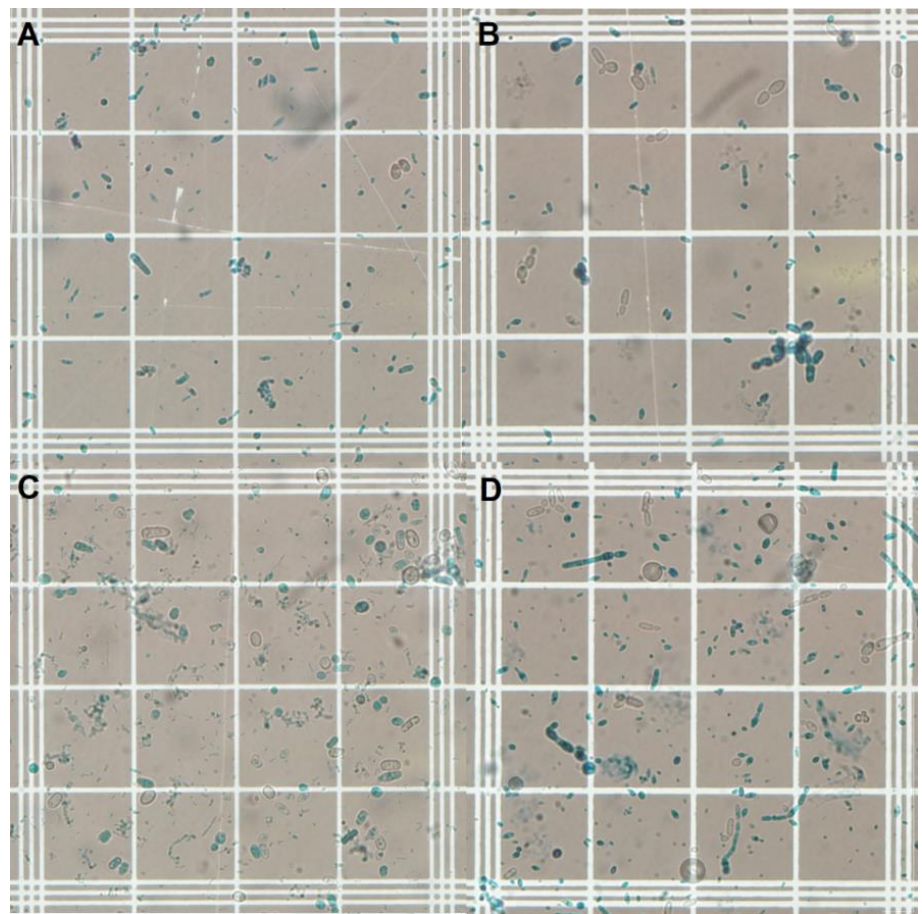

Figure 6 Yeasts of the four types of mead in the Neubauer chamber on the 57 th day of the process. A) Mead of type A. B) Mead of type B. C) Mead of type C. D) Mead of type D.

The second analysis shows the improvement in viability in types B and D meads, indicating that the addition of sodium hydroxide had the expected effect, with type B viability increasing to $22.03 \%$ while type D increasing to $27.91 \%$, however the viability of types $\mathrm{A}$ and $\mathrm{C}$ decreased, with type A reduced to $4.92 \%$, while type $\mathrm{C}$ reduced to $22.39 \%$, due to the high concentration of ethanol in the fermented medium, since According to Oliveira et al. (2001) the main responsible for the decrease in cell viability in alcoholic fermentation is the product of the fermentation itself.

\section{CONCLUSION}

It is concluded that it is possible to make artisanal mead through natural fermentation, using wild yeasts. However, that during the fermentation process it is necessary to take extra care so that the process is carried out entirely in anaerobiosis so that there is no contamination with microorganisms that produce acetic acid and methanol, as this transforms the mead, which is the desired product, into vinegar of honey or unfit for human consumption. In spite of this, further assessments are necessary to verify whether the differences found in the four types of meads are repeated and whether the yeasts found in Type C mead are really more efficient, as well as whether the yeasts of the four meads will always differ each other.

In view of the results presented in this work, a reassessment of the quality and identity standards established by Normative Instruction No. 34/2012 for mead is considered appropriate, with the addition of a methanol content parameter in the fermented honey drink and by conducting a study more detailed to verify the real origin of methanol.

\section{REFERENCES}

Abadio Finco, F. D. B., Moura, L. L., \& Silva, I. G. (2010). Propriedades físicas e químicas do mel de Apis mellifera L. Food Science and Technology, 30(3), 706-712. https://doi.org/10.1590/S0101-20612010000300022

Adolfo Lutz INSTITUT. (2008). Métodos físico-químicos para análise de alimentos. São Paulo: Instituto Adolfo Lutz, 4.

Andrietta, M. G. S., Andrietta, S. R., Steckelberg, C., \& Stupiello, E. N. A (2007). Brazil, 30 years of Proálcool. International Sugar Journal, 109(1299) 195-200. http://hdl.handle.net/11449/69535

Aquarone. E., Lima, U. A. L., \& Borzani, W. (1986). Alimentos e Bebidas Produzidos por Fermentação. São Paulo: Ed. Edgard Blücher Ltda, 5

Azeredo, L. C., Azeredo, M. A. A., \& Dutra, V. M. L. (2003). Protein contents and physicochemical properties in honey samples of Apis mellifera of different floral origins. Food Chemistry, 80, 249-2543. https://doi.org/10.1016/S03088146(02)00261-3

Bacaxixi, P., Bueno, C. E. M. S., Ricardo, H. A., Epiphanio, P. D., Silva, D. P., Barros, B. M. C., Silva, T. F., Bosquê, G. G., \& Lima, F. C. C. (2011). A importância da apicultura no Brasil. Revista Científica Eletrônica de Agronomia 10(20).
Berry, B. The global mead market: opportunities for canadian mead exporters. Ottawa, Ontário; Agriculture and Agri-Food Canada, 2007 http://www.agr.gc.ca/eng/programs-and-services/list-of-programsandservices/agri-food-trade-service/?id=1410965065217. date of access 09.09.2019.

Brazil (2012). Ministério da Agricultura e do abastecimento. Instrução Normativa $\mathrm{n}^{\circ}$ 34, de 29 de novembro de 2012. Regulamento Técnico de Identidade e Qualidade das bebidas fermentadas: fermentado de fruta; fermentado de fruta licoroso; fermentado de fruta composto; sidra; hidromel; fermentado de cana; saquê ou sake. Diário Oficial da República Federativa do Brasil, Brasília, DF, 23 nov. 2012. Seção 1, p. 3

Brazil. (2013). Ministério Da Agricultura, Pecuária e Abastecimento. Secretaria de Defesa Agropecuária. Bebidas Alcoólicas Fermentadas. Brasília, Brazil.

Brazil. (2018). Ministério da Agricultura e do abastecimento. Instrução Normativa $\mathrm{n}^{\circ} 14$, de 08 de fevereiro de 2018. Complementação dos Padrões de Identidade e Qualidade do Vinho e Derivados da Uva e do Vinho. Diário Oficial da República Federativa do Brasil, Brasília, DF, 09 mar. 2018. Seção 1, p. 4-5-6. Brunelli, L. T. (2015). Caracterização físico-química, energética e sensorial de hidromel. Universidade Estadual Paulista, PhD thesis, Botucatu, Brazil

Campos, L. (2015). A sacralidade que vem das taças: o uso de bebidas no Mito e na Literatura Nórdica Medieval. Revista Brasileira de História e Religião, 8(23) 97-107, 2015. https://doi.org/10.4025/rbhranpuh.v8i23.29528

Castro, R. D., \& Lima, E.O. (2011). Screening da Atividade Antifúngica de Óleos Essenciais. Pesquisa Brasileira de Odontopediatria Clinica Integral 11(3), 341-345. https://doi.org/10.4034/PBOCI.2011.113.06

Ceccato-Antonini, S. R. (2010). Microbiologia da fermentação alcoólica: a importância do monitoramento microbiológico em destilarias. São Carlos: EdUFSCar.

Ceccato-Antonini, S. R., Parazzi, C. (1996). Isolamento de levedura selvagem floculante e efeitos da contaminação em processo de fermentação etanólica contínua: Anais do Congresso Nacional da STAB.

Embrapa. (2003). Embrapa meio norte. Apicultura: Sistema de Produção, 3. Online version.

EU. (2012). Regulamento (EU) $\mathrm{n}^{\circ} 1151 / 2012$ do Parlamento Europeu e do Conselho, relativo aos regimes de qualidade dos produtos agrícolas e dos gêneros alimentícios.

http://eurlex.europa.eu/LexUriServ/LexUriServ.do?uri=OJ:C:2013:166:0008:001 2:PT:PDF. date of access: 09.09.2019.

Falasca, M. T., Muchagata, E. A., \& Bassan, C. F. D. (2010). Vinho de Mel (hidromel) a partir do mel de Abelhas produzido pelo açúcar de cana-de-açúcar: Anais do fórum de pesquisa e extensão anais da Universidade de Marília.

Fernandes, D., Locatelli, G. O., \& Scartazzini, S. L. (2009). Avaliação de diferentes estirpes da levedura Saccharomyces cerevisiae na produção de hidromel, utilizando méis residuais do processo de extração. Evidência. 9(1-2), $29-42$

Ferrari, S. E., Lopes, J. J. C., Leme, J. R. A., \& Oliveira, E. R. (1980). Industria efficiency of alcohol fermentation: a comparative study: International Symposium of the Alcohol Fuels Technology. Proceedings... São Paulo: IPT, 1, 1139-141.

Fertonani, H. C. R. (2006). Estabelecimento de um modelo de extração ácida de pectina de bagaço de maçã. Univerisde Estadual de Ponta Grossa, M. Sc. Dissertation. Ponta Grossa, Brazil.

Freitas, A. G., Lima, T. S., Dourado, J. A., \& Souza, R. M. D. (2017). Hidromel uma opção de renda para o apicultor. Higiene alimentar, 36-40.

Gomes, T. M. C. (2010). Produção de Hidromel: efeito das condições de fermentação Escola Superior Agrária de Bragança, M. Sc. Dissertation. Bragança, Portugal.

Iglesias, A., Pascoal, A., Choupina, A. B., Carvalho, C. A.; Feás, X., \& Estvinho, L. M. (2014). Developments in the Fermentation Process and Quality Improvement Strategies for Mead Production. Molecules, 19(8), 12577-12590. https://doi.org/10.3390/molecules 190812577

Katz, S. E. (2012). The Art of Fermentation: An In-depth Exploration of Essential Concepts and Processes From Around the World. White River Junction, Vt.: Chelsea Green Pub.

Kosker, O., Feller, C. R., \& Esselen, W. B. (1949). Mustard as a preservative for fruit juices. New York: Glass Packer. 28, 818-823.

Kristbergsson, K., \& Oliveira, J. (2016). Traditional foods General and Consumer Aspects. Boston: Springer. http://doi.org/10.1007/978-1-4899-7648-2 Lauermann, B., Rezende, R. F. M., Rodrigues, T. V. D., Azevedo, M. L., \& Lucchese, M. M. (2015). Caracterização de mel e hidromel via espectroscopia Raman: Anais do VII Salão Internacional de Ensino, Pesquisa e Extensão Universidade Federal do Pampa.

Levigne, S., Ralet, M. C., \& Thibault, J. F. (2002). Characterization of pectins extracted from fresh sugar beet under different conditions using an experimenta design. Carbohydrate Polymers, 49, 145-153. https://doi.org/10.1016/s0144 8617(01)00314-9

Mattietto, R. A., LIMA, F. C. C., Venturieri, G. C., \& Araújo, A. A. (2006) Tecnologia para obtenção artesanal de Hidromel do tipo doce. Embrapa Comunicado Técnico 170, 1-5. 
Mendonça, L. M. V. L., Conceição, A., Piedade, J., Carvalho, V. D., \& Theodoro, V. C. A. (2006). Caracterização da composição química e do rendimento dos resíduos industriais do limão Tahiti (Citrus latifólia Tanaka). Ciência e Tecnologia de Alimentos, 26(4), 870-874. https://doi.org/10.1590/S0101-20612006000400025

Mileski, J. P. F. (2016). Produção e caracterização de hidromel utilizando diferentes cepas de leveduras Saccharomyces. Universidade Tecnológica Federal do Paraná, M. Sc. dissertation, Londrina, Brazil.

Moreira, B. L. D., Parazzi, C., Papin, L. F., \& Lopes, J. J. C. (2013). Estudo de linhagens de leveduras Saccharomyces cerevisiae oriundas da biodiversidade ambiental na fermentação alcoólica. Biosciense Journal, 29(1), 1672-1677.

Oliveira Neto, P. C. (2013). Tecnologia para obtenção de hidromel tipo doce.

Universidade Estadual da Paraíba, Graduation dissertation. Campina Grande, Brazil.

Oliveira, L. P., Maeda, R., Andrade, J. S., Pereira Junior, N., Carvalho, S. M. S. \& Astolfi Filho, S. (2001). Processo Fermentativo para Produção de Bebida Alcoólica de Pupunha (Bactris gasipaes Kunth). Biotecnologia, Ciência e Desenvolvimento, 3(19), 50-54.

Oliveira-Freguglia, R. M., \& Horii, J. (1998). Viabilidade celular de Saccharomyces cerevisiae em cultura mista com Lactobacillus fermentum. Journal Scientia Agricola, 55(3), 520-527. https://doi.org/10.1590/S010390161998000300022

Ourives, E. A. A. (1997). Avaliação da atividade antimicrobiana de condimentos vegetais (ervas aromáticas) em meio de cultura e peito de frango picado frente a $P$. fluorescens. Universidade Federal de Santa Catarina, PhD. thesis. Florianópolis, Brazil.

Parazzi, C., \& Oliveira, M. C. F. L. (1996). Comparação de linhagens de leveduras Saccharomyces cerevisiae floculantes em processo descontínuo de produção de álcool e aguardente: Anais do Congresso Nacional da STAB.

Peixoto, S., Carvalho, C. A., \& Estvinho, L. (2014). Produção de hidrome utilizando mel de Melipona scutellaris: III Congresso Ibérico de Apicultura, 66.

Pereira, A. P. R. (2008). Caracterização de mel com vista à produção de hydromel. Instituto Politécnico de Bragança. M.Sc. dissertation. Bragança, Portugal.

Picoli, P. O. (2011) Projeto pro-mel. Revista Mensagem Doce http://www.apacame.org.br/mensagemdoce/56/msg56.htm. date of access 10.10.2019.

Ribeiro Junior, M. R., Canaver, A. B., \& Bassan, C. F. (2015). Mead production physical-chemical and sensory analysis. Unimar Ciências, 24(1-2), 59-63.

Roldán, A., Muiswinkel, G., Lasanta, C., Palacios, V., \& Caro, I. (2011). Influence of pollen addition on mead elaboration: Physicochemical and sensory characteristics. Food Chemistry, 126, 574-582. https://doi.org/10.1016/j.foodchem.2010.11.045

Sarto, M. P. M., \& Zanusso Junior, G. (2014). Atividade antimicrobiana de óleos essenciais. Uningá Review, 20(1), 98-102.

Silva, M. S. (2016). Desenvolvimento de fermento para produção de hidromel. Universidade Federal de Viçosa, PhD thesis, Viçosa, Brasil.

Silva, P. M., Gauche, C., Gonzaga, L. V., Costa, A. C. O., \& Feit, R. (2016). Honey: Chemical composition, stability and authenticity. Food Chemistry, 196, 309-323. http://doi.org/0.1016/j.foodchem.2015.09.051

Silva, R. N., Monteiro, V. N., Alcanfor, J. D. X., Assis, E. M., \& Asquieri, E. R. (2003). Comparação de métodos para a determinação de açúcares redutores totais em mel. Ciência e Tecnologia de Alimentos, 23, 337-341. https://doi.org/10.1590/S0101-20612003000300007

Souza, P. L. N., Dias, F. D., \& Teixeira, N. C. (2018). Produção Artesanal de Um Hidromel de Acerola Orgânica. Revista Pensar Gastronomia, 4(1).

Vicente, F. A. C. F. (2015). Seleção, avaliação e utilização de uma levedura personalizada para a produção de etanol. Universidade Estadual Paulista, PhD. thesis. São José do Rio Preto, Brazil 2015.

Wansink, B., Cheney, M. M., \& Chan, N. (2003). Exploring comfort food preferences across age and gender. Physiology \& Behavior, 79(4-5), 739-747. https://doi.org/10.1016/S0031-9384(03)00203-8

Yapo, B. N., Robert, C., Etienne, I., Wathelet, B., \& Paquot, M. (2006). Effect of extraction conditions on the yield, purity and surface properties of sugar beet pulp pectin extracts. Food Chemistry, 100, 1356-1364 https://doi.org/10.1016/j.foodchem.2005.12.012 